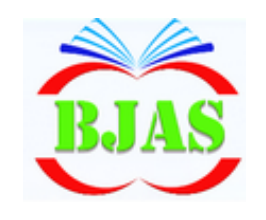

ISSN $1814-5868$
Available online at http://bjas.bajas.edu.iq

https://doi.org/10.37077/25200860.2021.34.1.06

College of Agriculture, University of Basrah

Basrah J. Agric. Sci. 34(1): 60-66, 2021

\section{Basrah Journal of Agricultural Sciences}

E-ISSN: 2520-0860

\title{
Effect of Different Levels of Local Concentrated Protein Manufactured from Slaughterhouse Wastes on some Carcasses Traits of Broiler
}

\author{
Zaman K.F. Al-Mhsenawi ${ }^{1}$, Majid H.A. Alasadi ${ }^{2}$ \& Qutiba J.G. Al khfaji ${ }^{2}$ \\ ${ }^{1}$ Department of Biology, College of Education for Pure Science, University of Al- \\ Muthanna, Iraq. \\ ${ }^{2}$ Department of Animal Production, College of Agriculture, University of Basrah, Iraq. \\ * Corresponding author e-mail: zmnkhdr@gmail.com
}

Received 16 June 2020; Accepted 16 October 2020; Available online 10 February 2021

\begin{abstract}
This study was conducted to determine the effect of different levels of local concentrated protein extracted from slaughterhouse wastes on some carcasses traits of broiler. A total of 225 female broiler Ross 308 chicks, one day, were used, randomized distributed into five treatments, with three replicates per treatment (15 chicks each replicate). The treatments were as follows: T1; basal diet contains $4 \%$ imported protein. T2; basal diet contains $2 \%$ imported protein $+2 \%$ local manufactured protein. T3; basal diet contains $4 \%$ local manufactured protein. T4; basal diet contains $6 \%$ local manufactured protein. T5; basal diet contains $8 \%$ local manufactured protein. The results showed that there were no significant differences between the treatments on the carcass weight, dressing percentage, relative weights of the thigh and breast, as well as the relative weight of the abdominal fat. There were no significant differences among all treatments for the sensory traits of the thigh and breast. In conclusion, the locally manufactured animal protein extraction had no negative significant effect on the characteristics of carcasses and could be used as an efficient alternative to imported protein concentration used in broiler diets.
\end{abstract}

Keywords: Local protein, Slaughterhouse wastes, Carcasses traits, Broiler.

\section{Introduction}

Nutrition constitutes $70 \%$ or more of the total cost of poultry production and has a direct impact on the production process. Therefore, special attention must be paid to nutrition (Abdelmageed, 2012). The feed components significantly affect the growth of meat and the productivity of laying hens, so the diet should contain all nutrients in a balanced way according to the needs of the bird
(Puvadolpirod \& Thaxton, 2000). The poultry industry is dependent on imported protein concentrates in Iraq, it is the main source of animal protein, vitamins, minerals and some feed additives in poultry diets, however, the high prices increase the production cost (AlAthary, 2002). Thousands of tons of poultry waste are dumped annually, 


\section{Al-Mhsenawi et al. / Basrah J. Agric. Sci., 34(1): 60-66, 2021}

like heads, legs, feathers and intestines, disposed of as waste or used as animal fertilizers, due to the availability of the waste in large quantities, it has become an environmental problem (Al-Tai, 2005). Therefore, some studies have tended to be used in the production of protein concentrates, involves the composition of animal diets, especially poultry and fish, modern technologies were used to convert these animal wastes into beneficial materials for animal feeding, and preserving the environment from the accumulation of these substances, and impact on public health (Ibrahim, 2000).

The researchers resorted to the use of chemical methods using acid, alkaline and salt, these methods were characterized by the short time of decomposition, cheapness and easy, in addition to enzymatic methods. There are a lot of studies that try to make a protein that competes with the imported protein, good progress has been made in this field, but there was no perpetuation of these actions (Ahmed et al., 2018; Frempong et al., 2019).

The aim of this study to manufacture a protein concentrate from the carcass waste (heads and legs), and add it into diets as an alternative to the imported protein concentrate, study the effect on some carcasses traits of broiler.

\section{Materials \& Methods}

The study was conducted at poultry farm, Agriculture College, University of Basrah, from $11 \backslash 11 \backslash 2019$ to $16 \backslash 12 \backslash 2019$. A total of 225 female broiler Ross 308 chicks, one day old, 40 $\mathrm{g}$ weight were randomly distributed into five treatments, with three replicates per treatment (15 chicks each replicate). Chickens are bred in three-story cages with an area of $1 \mathrm{~m}^{2}$ per cage. Provides appropriate conditions for rearing such as heat and ventilation, within the necessary limits, the chicks were fed on two types of diets, the first Starter diet (1-21 days) and the second the grower diet (22-35 days), as shown in table (1).

\section{Protein concentrate preparing}

Broiler heads and legs were collected from the poultry field slaughter house, Agriculture College, University of Basrah, and washed with water, chopped with an electric mincer, then was exposed to steam at $140^{\circ} \mathrm{c}$ for 50 minutes (Wiradimadja et al., 2014), the product was dried at $45 \mathrm{c}^{\circ}$ and the resulting material was ground. After analyzing a sample of a protein content, to ensure chemical composition and amino acid content by using a device Amino acid Analyzer, according to the results of the laboratory examination reached, the protein composition was modified by mixing with the amino acid, vitamins and minerals (Wafi), according to the ratio 3 protein products +1 Wafi mixture.

\section{Study traits}

Six birds per treatment were slaughtered randomly at 35 days of age to calculate the carcass weight and dressing percentage, and relative weight of carcass cuts were calculated according to the method mentioned by Zangana \& Al-Mashhadani (2018). The relative weight of abdominal fat to body weight was estimate according to Al-Hummod (2016). Sensory tests for thigh and breast cuts were conducted according to the method described by Yang et al. (2007). The degree of the sensory evaluation were determined according to table (2). 
Al-Mhsenawi et al. / Basrah J. Agric. Sci., 34(1): 60-66, 2021

Table (1): The composition of the diets used and chemical analysis during the starter and grower periods.

\begin{tabular}{|c|c|c|c|c|c|}
\hline \multirow{2}{*}{$\begin{array}{ll}\text { Items } & \text { Treatments } \\
\end{array}$} & \multicolumn{5}{|c|}{ Starter diet (1-21 days) } \\
\hline & T1 & $\mathrm{T} 2$ & T3 & $\mathrm{T} 4$ & T5 \\
\hline Maize & 42.5 & 42.7 & 42.7 & 42.7 & 42.2 \\
\hline Wheat & 18 & 18 & 18 & 18 & 18 \\
\hline Soybean meal & 32 & 32 & 32 & 30 & 28.5 \\
\hline Imported protein conc. $*$ & 4 & 2 & 0 & 0 & 0 \\
\hline Local protein conc. Manufactured** & 0 & 2 & 4 & 6 & 8 \\
\hline PREMIXES*** & 1 & 1 & 1 & 1 & 1 \\
\hline Limestone & 2 & 2 & 2 & 2 & 2 \\
\hline Plant oil & 0.5 & 0.5 & 0.5 & 0.5 & 0.5 \\
\hline Total & 100 & 100 & 100 & 100 & 100 \\
\hline \multicolumn{6}{|c|}{ Chemical Analysis } \\
\hline Crude protein (\%) & 23.1 & 23.1 & 23.1 & 22.9 & 22.9 \\
\hline Metabolizable energy (kcal.kg-1) & 2954 & 2950 & 2957 & 2959 & 2955 \\
\hline Treatments & \multicolumn{5}{|c|}{ grower diet (22-35 days) } \\
\hline Items & $\mathrm{T} 1$ & $\mathrm{~T} 2$ & T3 & $\mathrm{T} 4$ & T5 \\
\hline Maize & 46.5 & 46.5 & 46.5 & 46.5 & 46 \\
\hline Wheat & 18 & 18 & 18 & 18 & 18 \\
\hline Soybean meal & 27.5 & 27.5 & 27.5 & 25.5 & 24 \\
\hline Imported protein conc.* & 4 & 2 & 0 & 0 & 0 \\
\hline Local protein conc. manufactured & 0 & 2 & 4 & 6 & 8 \\
\hline PREMIXES & 1 & 1 & 1 & 1 & 1 \\
\hline Limestone & 1.5 & 1.5 & 1.5 & 1.5 & 1.5 \\
\hline Plant oil & 1.5 & 1.5 & 1.5 & 1.5 & 1.5 \\
\hline Total & 100 & 100 & 100 & 100 & 100 \\
\hline \multicolumn{6}{|c|}{ Chemical Analysis } \\
\hline Crude protein $(\%)$ & 21.3 & 21.3 & 21.4 & 21.1 & 21.1 \\
\hline Metabolizable energy (kcal.kg-1) & 3072 & 3070 & 3072 & 3066 & 3047 \\
\hline
\end{tabular}

* The protein concentrate for broiler feeding (Brocorn-5 special W) produced by the company (Wafi B.V. AlblasserdamHolland), chemical composition: $40 \%$ crude protein, $5 \%$ crude fat, $2.20 \%$ crude fiber, $7.10 \%$ Moisture, $28.30 \%$ crude ash, 4.20\% Calcium, 4.65\% Phosphorus, 2107 Met. energy (kcal/g).

** Local protein conc. manufactured, chemical composition: $42.79 \%$ crude protein, $8.69 \%$ crude fat, $2.7 \%$ crude fiber, 7.32\% Moisture, $21.72 \%$ crude ash, $4.2 \%$ Calcium and 3\% Phosphorus.

*** Premixes, chemical composition: $10 \%$ crude protein, $2.1 \%$ crude fat, $0.34 \%$ crude fiber, $2.66 \%$ Moisture, $51.02 \%$ crude ash, $20.08 \%$ Calcium, 10.83\% Phosphorus, $753.82 \mathrm{kcal} \mathrm{kg} \mathrm{Met.} \mathrm{energy} \mathrm{(kcal.g} \mathrm{g}^{-1}$ ).

\section{Statistical analysis}

A Complete Randomized Design (CRD) were used, the significant differences between the means were compared with Least Significant Difference (LSD) test with a significant level (P
$<0.05$ ), the SPSS program (SPSS, 2017) was used in statistical analysis and use the following mathematical model $\left(y_{i j}=\mu+t_{i}+\right.$ eij). 
Al-Mhsenawi et al. / Basrah J. Agric. Sci., 34(1): 60-66, 2021

Table (2): Sensory evaluation of cooked breast and thigh meat traits (Hajem, 2018).

\begin{tabular}{|c|c|c|c|c|c|}
\hline \multicolumn{6}{|c|}{ Sensory evaluation menu } \\
\hline \multicolumn{2}{|c|}{ Degree } & Evaluation & \multicolumn{2}{|c|}{ Degree } & Evaluation \\
\hline \multicolumn{2}{|l|}{9} & Excellent & \multicolumn{2}{|l|}{$5-6$} & Moderate \\
\hline \multicolumn{2}{|l|}{8} & Very good & \multicolumn{2}{|l|}{$3-4$} & Acceptable \\
\hline \multicolumn{2}{|l|}{7} & Good & \multicolumn{2}{|l|}{$2-1$} & Unacceptable \\
\hline N. Sample & Colour & Flavor & Tenderness & Juiciness & $\begin{array}{c}\text { General } \\
\text { acceptance }\end{array}$ \\
\hline 1 & & & & & \\
\hline 2 & & & & & \\
\hline 3 & & & & & \\
\hline 4 & & & & & \\
\hline 5 & & & & & \\
\hline
\end{tabular}

\section{Results \& Discussions}

Table (3) shows that no significant differences of the use of local manufactured protein concentrate on the carcasses traits (carcass weight, dressing percentage, relative weight of main cuts and abdominal fat).

The results agreed with Sahraei et al. (2012), indicated that there were no significant differences on the carcasses weights and the relative weight of the main cuts (breast and thigh) when used the poultry slaughterhouse waste powder as a source of protein into broiler diets in ratios (30, 60 and 90 g.kg feed $\left.{ }^{-1}\right)$. While the results were not agreed with those of Ahmed et al. (2018), indicated improve in the carcass weight, dressing percentage and main cuts weight, when they use slaughterhouse wastes as a protein concentrate in broiler diets, T4 (15\% slaughterhouse wastes) was a significant increase $(\mathrm{P}<0.05)$ in carcass weight, while the dressing percentage and weights for breast and thigh were better at T3 (10\% slaughterhouse wastes).

The result agreed with that of Abiola et al. (2012), they concluded that there were no significant differences in the relative weight of abdominal fat, when they replaced fish meal with poultry hatching powder in broiler diets. However, Sahraei et al. (2012), observed a significant differences $(\mathrm{P}<0.05)$ in the relative weight of abdominal fat between a control and 
Al-Mhsenawi et al. / Basrah J. Agric. Sci., 34(1): 60-66, 2021

Table (3): The effect of different level of the local protein concentrate manufactured on some carcasses traits of broiler (Mean $\pm \mathrm{SE})$.

\begin{tabular}{|c|c|c|c|c|c|c|}
\hline Treatments & Body weight (g) & Carcass weight $(\mathrm{g})$ & $\begin{array}{c}\text { Dressing } \\
\text { percentage } \\
(\%)\end{array}$ & $\begin{array}{l}\text { Relative } \\
\text { weight of } \\
\text { thigh }(\%)\end{array}$ & $\begin{array}{c}\text { Relative } \\
\text { weight of } \\
\text { breast }(\%)\end{array}$ & $\begin{array}{c}\text { Relative weight } \\
\text { of abdominal } \\
\text { fat }(\%)\end{array}$ \\
\hline T1 & $\begin{array}{c}1782.30 \pm 1.85 \\
\mathrm{a}\end{array}$ & $\begin{array}{c}1261.00 \pm 2.1 \\
\mathrm{a}\end{array}$ & $\begin{array}{c}70.74 \pm 0.04 \\
\mathrm{a}\end{array}$ & $\begin{array}{c}20.90 \pm 0.87 \\
\mathrm{a}\end{array}$ & $\begin{array}{c}37.74 \pm 1.30 \\
\mathrm{a}\end{array}$ & $\begin{array}{c}0.51 \pm 0.04 \\
\mathrm{a}\end{array}$ \\
\hline $\mathbf{T 2}$ & $\begin{array}{c}1780 \pm 1.73 \\
\mathrm{a}\end{array}$ & $\begin{array}{c}1255.00 \pm 1.51 \\
\mathrm{a}\end{array}$ & $\begin{array}{c}70.50 \pm 0.20 \\
\mathrm{a}\end{array}$ & $\begin{array}{c}20.57 \pm 1.42 \\
\mathrm{a}\end{array}$ & $\begin{array}{c}37.68 \pm 1.41 \\
\mathrm{a}\end{array}$ & $\begin{array}{c}0.50 \pm 0.05 \\
\mathrm{a}\end{array}$ \\
\hline T3 & $\begin{array}{c}1778 \pm 2.08 \\
\mathrm{a}\end{array}$ & $\begin{array}{c}1264.00 \pm 2.08 \\
\mathrm{a}\end{array}$ & $\begin{array}{c}71.08 \pm 0.19 \\
\mathrm{a}\end{array}$ & $\begin{array}{c}21.22 \pm 1.10 \\
\mathrm{a}\end{array}$ & $\begin{array}{c}39.32 \pm 0.76 \\
\mathrm{a}\end{array}$ & $\begin{array}{c}0.49 \pm 0.02 \\
\mathrm{a}\end{array}$ \\
\hline T4 & $\begin{array}{c}1779 \pm 2.06 \\
\mathrm{a}\end{array}$ & $\begin{array}{c}1256.70 \pm 3.33 \\
\mathrm{a}\end{array}$ & $\begin{array}{c}70.69 \pm 0.19 \\
\mathrm{a}\end{array}$ & $\begin{array}{c}21.34 \pm 1.29 \\
\mathrm{a}\end{array}$ & $\begin{array}{c}39.91 \pm 0.48 \\
\mathrm{a}\end{array}$ & $\begin{array}{c}0.50 \pm 0.03 \\
\mathrm{a}\end{array}$ \\
\hline T5 & $\begin{array}{c}1790 \pm 0.57 \\
\mathrm{a}\end{array}$ & $\begin{array}{c}1261.00 \pm 5.68 \\
\mathrm{a}\end{array}$ & $\begin{array}{c}70.88 \pm 0.30 \\
\mathrm{a}\end{array}$ & $\begin{array}{c}22.41 \pm 0.92 \\
\mathrm{a}\end{array}$ & $\begin{array}{c}38.91 \pm 0.85 \\
\mathrm{a}\end{array}$ & $\begin{array}{c}0.51 \pm 0.02 \\
\mathrm{a}\end{array}$ \\
\hline
\end{tabular}

T1; basal diet contains $4 \%$ imported protein. T2; basal diet contains $2 \%$ imported protein $+2 \%$ local manufactured protein. T3; basal diet contains $4 \%$ local manufactured protein. T4; basal diet contains $6 \%$ local manufactured protein. T5; basal diet contains $8 \%$ local manufactured protein.

treatment of the slaughterhouse wastes broiler diets. Tables (4 and 5) were showed that the effect of using different level of the local protein concentrated manufactured on the sensory traits of the breast and thigh cuts of broilers. There is no significant differences between the local protein concentrated manufactured and imported protein concentrate on colour, flavor, tenderness, juiciness and general acceptance of the cuts of breast and thigh. We can conclude it has no significant differences of the use of local protein. The present results are similar to those of Eyng et al. (2013), when they used tilapia powder (fish meal) as a source of protein of different levels in broiler diets as their results showed that adding tilapia powder to diets in ratios 2, 4, 6 and $8 \%$ had no effect on the sensory characteristics (aroma, flavor, colour, texture and whole quality) of the thigh and breast meat, while the results were not agreed with results of Al-Hummod \& Mohsen (2019),

Table (4): The effect of different level of the local protein concentrate manufactured on sensory traits of breast cut (Mean $\pm \mathrm{SE})$.

\begin{tabular}{|c|c|c|c|c|c|}
\hline Treatments & Colour & Flavor & Tenderness & Juiciness & \multirow{2}{*}{ General acceptance } \\
\hline T1 & $7.33 \pm 0.33 \mathrm{a}$ & $7.50 \pm 0.29 \mathrm{a}$ & $6.86 \pm 0.67 \mathrm{a}$ & $7.13 \pm 0.13 \mathrm{a}$ & $6.90 \pm 0.29 \mathrm{a}$ \\
\hline T2 & $7.33 \pm 0.37 \mathrm{a}$ & $7.50 \pm 0.29 \mathrm{a}$ & $6.83 \pm 0.33 \mathrm{a}$ & $6.95 \pm 0.58 \mathrm{a}$ & $7.00 \pm 0.58 \mathrm{a}$ \\
\hline T3 & $7.67 \pm 0.33 \mathrm{a}$ & $7.33 \pm 0.88 \mathrm{a}$ & $6.77 \pm 0.33 \mathrm{a}$ & $7.67 \pm 0.67 \mathrm{a}$ & $7.17 \pm 0.17 \mathrm{a}$ \\
\hline T4 & $7.66 \pm 0.67 \mathrm{a}$ & $8.00 \pm 0.29 \mathrm{a}$ & $6.73 \pm 0.67 \mathrm{a}$ & $6.98 \pm 0.52 \mathrm{a}$ & $6.92 \pm 0.00 \mathrm{a}$ \\
\hline T5 & $8.00 \pm 0.57 \mathrm{a}$ & $7.67 \pm 0.67 \mathrm{a}$ & $7.00 \pm 0.25 \mathrm{a}$ & $7.33 \pm 0.33 \mathrm{a}$ & $7.07 \pm 0.23 \mathrm{a}$ \\
\hline
\end{tabular}


Al-Mhsenawi et al. / Basrah J. Agric. Sci., 34(1): 60-66, 2021

T1; basal diet contains $4 \%$ imported protein. T2; basal diet contains $2 \%$ imported protein $+2 \%$ local manufactured protein. T3; basal diet contains $4 \%$ local manufactured protein. T4; basal diet contains $6 \%$ local manufactured protein. T5; basal diet contains $8 \%$ local manufactured protein.

Table (5): The effect of different level of the local protein concentrate manufactured on sensory traits of thigh cut (Mean \pm SE).

\begin{tabular}{|c|c|c|c|c|c|}
\hline \multirow{2}{*}{$\begin{array}{c}\text { Traits } \\
\text { Treatments }\end{array}$} & Colour & Flavor & Tenderness & Juiciness & $\begin{array}{c}\text { General } \\
\text { acceptance }\end{array}$ \\
\hline T1 & $7.33 \pm 0.33 \mathrm{a}$ & $8.00 \pm 0.00 \mathrm{a}$ & $7.67 \pm 0.33 \mathrm{a}$ & $7.67 \pm 0.33 \mathrm{a}$ & $8.00 \pm 0.30 \mathrm{a}$ \\
\hline T2 & $8.00 \pm 0.58 \mathrm{a}$ & $8.33 \pm 0.33 \mathrm{a}$ & $6.94 \pm 0.29 \mathrm{a}$ & $8.00 \pm 0.58 \mathrm{a}$ & $8.00 \pm 0.38 \mathrm{a}$ \\
\hline T3 & $8.16 \pm 0.60 \mathrm{a}$ & $7.83 \pm 0.44 \mathrm{a}$ & $6.96 \pm 0.33 \mathrm{a}$ & $7.67 \pm 0.16 \mathrm{a}$ & $8.17 \pm 0.44 \mathrm{a}$ \\
\hline T4 & $7.33 \pm 0.33 \mathrm{a}$ & $7.67 \pm 0.33 \mathrm{a}$ & $7.50 \pm 0.29 \mathrm{a}$ & $7.67 \pm 0.33 \mathrm{a}$ & $7.67 \pm 0.17 \mathrm{a}$ \\
\hline T5 & $7.33 \pm 0.33 \mathrm{a}$ & $8.33 \pm 0.14 \mathrm{a}$ & $7.67 \pm 0.33 \mathrm{a}$ & $7.50 \pm 0.28 \mathrm{a}$ & $7.50 \pm 0.28 \mathrm{a}$ \\
\hline
\end{tabular}

T1; basal diet contains $4 \%$ imported protein. T2; basal diet contains $2 \%$ imported protein $+2 \%$ local manufactured protein. T3; basal diet contains $4 \%$ local manufactured protein. T4; basal diet contains $6 \%$ local manufactured protein. T5; basal diet contains $8 \%$ local manufactured protein.

which showed a significant differences $(\mathrm{P} \leq 0.05)$ in the flavor of quail meat fed on a diet containing protein concentrate made from feathers compared to quail meat fed on a diet containing commercial protein concentration.

The local manufactured protein were similar to the results of the imported protein. Also, the absence of significant differences between control and other experimental treatments for the mentioned characteristics, indicates that the processed protein is not less efficient than the imported, to complete the birds' requirements from essential amino acids, in proportion to the different supplies of the body, whether in growth, production, or formation of hormones and enzymes that have important vital functions in the body.

\section{Conclusions}

In conclusion, the locally manufactured animal protein extraction had no negative significant effect on the characteristics of carcasses and could be used as an efficient alternative to imported protein concentration used in broiler diets.

\section{Acknowledgments}

We thank the team of laboratory of Poultry Technology, College of Agriculture, University of Basrah and all who helped us in this work.

Z. Al-Mhsenawi:: https://orcid.org/0000-00034706-0951

M. Alasadi: https://orcid.org/0000-0001-58757485

Q. Al-khfaji: https://orcid.org/0000-00018347-230X )

\section{References}

Abdelmageed, M. A. A. (2012). Effect of dietary humic substance supplementation on performance and immunity of Japanese Quail. Egyptian Poultry Science Journal, $\quad 12, \quad 615-660$. 


\section{Al-Mhsenawi et al. / Basrah J. Agric. Sci., 34(1): 60-66, 2021}

https://www.semanticscholar.org/paper/EFFECT-OFDIETARY-HUMIC-SUBSTANCESSUPPLEMENTATION-

Abdelmageed/11d06702f3404acb1b4de8fc4085ec777 3df9baf

Al-Athary, A. K. (2002). Prepare mixtures of vitamins and rare minerals precooked locally (premix) and protein concentrates locally and use them in broiler rations. Journal Abaa of Agricultural Research, 12, 42-48. (In Arabic).

Abiola, S. S., Radebe, N. E., Westhuizen, C. V. D., \& Umesiobi, D. O. (2012). Whole hatchery waste meal as alternative protein and calcium sources in broiler diets. Archivos de Zootecnia., 61, 229-234. http://scielo.isciii.es/pdf/azoo/v61n234/art7.pdf

Ahmed, S., Uddin, M. J., Islam, M. A., \& Haque, M. E. (2018). Effect of graded levels of slaughter house residues on growth performance and hematological parameters in Broiler Chicken's Ration. Asian Research Journal of Agriculture, 9, 1-8. http://doi.org/ 10.9734/ARJA/2018/41409

Al-Hummod, S. K. M. (2016). The effect of lighting systems and temporal feed restriction on some productive, physiological and reproductive traits of Japanese quail. Ph. D. Thesis, College of Agriculture, University of Basrah, 225pp. (In Arabic).

Al-Hummod, K. M., \& Mohsen, S. B. (2019). Comparison of different types of protein concentrate in female Japanese quail diets and study their effect on production and sensory characteristics. Basrah Journal of Veterinary Research, 18, 56-66. https://www.iasj.net/iasj/download/16f91db9f7bf1bc6

Al-Tai, M. A. J. (2005). Food and drug products from fish and shrimp and their offal. Marina Mesopotamica, 20, 157-170. (In Arabic). https://www.iasj.net/iasj?func=fulltext\&aId=51444

Eyng, C., Nunes, R. V., Pozza, P. C., Murakami, A. E., Scherer, C., \& Schone, R. A. (2013). Carcass yield and sensorial analysis of meat from broiler chicken fed with tilapia byproducts meal. Ciência $e$ Agrotecnologia. 37, 451-456. https://doi.org/ 10.1590/S1413-70542013000500009

Frempong, N. S., Nortey, T.H. N. N., Paulk, C., \& Stark, C. R. (2019). Evaluating the effect of replacing fish meal in broiler diets with either soybean meal or poultry by-product Meal on broiler performance and total feed cost per kilogram of gain. Journal of Applied Poultry Research, 28, 912-918. http://dx.doi.org/10.3382/japr/pfz049

Hajem, M. H. A. (2019).Effect of the use of dried yoghurt as a (locally manufactured) and compared with imported probiotics in the some characteristics of productive, physiological, immunological and digestive of broiler. Submitted to the Council of the College of Agriculture University of Basrah, In Fulfillment of the Requirements for the Degree of Doctor Philosophy in Animal Production. Ph. D Thesis, College of Agriculture, University of Basrah, 171pp. (In Arabic).

Ibrahim, I. K. (2000). Poultry Feeding. Book House for Printing and Publishing, University of Mosul. 311pp. (In Arabic).

Sahraei, M., Lootfollahian, H., \& Ghanbari, A. (2012). Effect of poultry by product meal on performance parameters, serum Uric acid concentration and carcass characteristics. Iranian Journal of Applied Animal Science, $\quad 2, \quad 73-77$. http://ijas.iaurasht.ac.ir/article_514336_1c11af8dad67 4fb46f0c6ae08fa87a5c.pdf

SPSS, Statistical Package for the Social Sciences (2017). Quantitative Data Analysis with IBM SPSS version 25: A Guide for Social Scientists.

Puvadolpirod, S., \& Thaxton, T. P. (2000). Model of physiolocal stress in chickens: 1-Response parameters. Poultry Sceince, 79, 363-369. https://doi.org/10.1093/ps/79.3.363

Wiradimadja, R., Rusmana, D., Widjastuti1, T., \& Mushawwir, A. (2014). Chicken slaughterhouse waste utilization (chicken feather meal treated) as source of protein animal feed ingredients in broiler chickens. Iinţifice-Seria Zootehnie, 62, 120-124. https://pdfs.semanticscholar.org/3234/141df2e570a5a b65871a4e974d89fb3af172.pdf

Yang, H.-S., Choi, S.-G., Jeon, J.-T., Park, G.-B., \& Joo, S. T. (2007). Textural and sensory properties of low fat sausages with added hydrated oatmeal and tofu as texture-modifying agents. Meat Science, 75, 283-289. https://doi.org/10.1016/j.meatsci.2006.07.013 


\section{Al-Mhsenawi et al. / Basrah J. Agric. Sci., 34(1): 60-66, 2021}

Zangana, B. S. R., \& Al-Mashhadani, S. M. (2018). Effect of adding different level of marjoram (Origanum vulgare) powder to the diet in dress percentages and numeral of characteristics carcasses broiler. Diyala Agricultural Sciences Journal, 10, 4251.

https://www.iasj.net/iasj/download/e571f0ce5831aab 7

\section{تأثير استخدام نسب مختلفة من المركز البروتيني المصنع محليا من مخلفات المجازر في بعض صفات ذبائح}

فروج اللحم

زمن خضر فرعون المحسناوي1 وماجد حسن عبد الرضا الاسدي ² قو قتيبة جاسم غني الخفاجي2

1 قسم علوم الحياة، كلية التربية للعلوم الصرفة، جامعة المثنى، العراق

2 قسم الانتاج الحيواني، كلية الزراعة، جامعة البصرة، العراق

المستخلص: اجريت هذه الدراسة بهدف معرفة تأثير استخدام المركز البروتيني المصنع محليا في بعض صفات ذبائح فروج اللحم. استخدم في التجربة 225 فرخ فروج لحم (اناث) بعمر يوم (سلالة Ross-308) وزعت الافراخ عشوائيا على خمس معاملات و بواقع ثلاث مكررات (15 فرخ/ مكرر). وكانت معاملات التجربة كالاتي: المعاملة الاولى (السيطرة T1) قدم للأفراخ فيها عليقة تحتوي 4\%

بروتين مستورد، المعاملة الثانية(T2) قدم للأفراخ فيها عليقة تحتوي 2\% بروتين مستورد + 2\% بروتين مصنع، المعاملة الثالثة (T3) قدم للأفراخ فيها عليقة تحتوي 4\% بروتين مصنع، المعاملة الرابعة (T4) قدم للأفراخ فيها عليقة تحتوي 6\% بروتين مصنع والمعاملة الخامسة (T5) استخدام عليقة تحتوي 8\% بروتين مصنع. أظهرت النتائج انعدام الغروق المعنوية بين معاملات التجربة في وزن الذبيحة، نسبة التصافي، الاوزان النسبية لقطعيات الفخذ والصدر فضلا عن الوزن النسبي لدهن البطن. اما فيما يخص الصفات الحسية لقطعيات الفخذ والصدر فلم تكن هنالك اي فروق معنوية بين جميع المعاملات. نستتتج من هذه الدراسة ان المركز البروتيني الحيواني المصنع محليا لم يكن له تأثير معنوي على صفات الذبائح وبالإمكان استخدامه كبديل كفوء للمركزات البروتينية المستوردة والمستخدمة في علائق الفروج. الكلمات المفتاحية: البروتين المحلي، مخلفات المجازر، صفات الذبائح، فروج اللحم. 